\title{
EHMTI-0316. Exam findings predict outcome of C1 block for migraine treatment
}

\author{
M Johnston", SE Jordan, AC Charles \\ From 4th European Headache and Migraine Trust International Congress: EHMTIC 2014 \\ Copenhagen, Denmark. 18-21 September 2014
}

\section{Introduction}

Previous studies have shown the $\mathrm{C} 1$ spinal nerve has sensory neurons. Direct stimulation of the $\mathrm{C} 1$ spinal nerve provokes peri-orbital pain in migraine patients. No data exist which can predict a positive outcome for $\mathrm{C} 1$ nerve root block. Tenderness over the greater occipital nerve has been shown to predict outcome of GON block. We propose that tenderness over the GON with periorbital referral on exam predicts periorbital referral on direct $\mathrm{C} 1$ stimulation and predicts a positive outcome of block.

\section{Aims}

Predict the outcome of $\mathrm{C} 1$ spinal nerve block based on exam findings.

\section{Methods}

Review of 23 patients, 21 of whom had chronic migraine and 2 of whom had chronic cluster headache. All 23 have undergone $\mathrm{C} 1$ spinal nerve block.

\section{Results}

Of the 23 patients, 17 (74\%) had GON tenderness on exam with periorbital referred pain and $6(26 \%)$ had only occipital tenderness. Both cluster patients did not have periorbital nor orbital pain on palpation of the GON. All 17 with periorbital referred pain on GON palpation had reproducible periorbital pain intraoperatively on direct stimulation of the $\mathrm{C} 1$ spinal nerve with fluoroscopic guidance. Of those, $15 / 17$ (88\%) had a positive block. Of the $6 / 23$ (26\%) with a negative block, only two had periorbital pain reproduced on exam by GON palpation. Both cluster headaches had negative blocks. Neither had intraoperative periorbital or orbital pain on $\mathrm{C} 1$ stimulation.

Neurology, University of California Los Angeles, Los Angeles, USA

\section{Conclusion}

Tenderness over the GON with periorbital pain referral during exam predicts positive outcome of $\mathrm{C} 1$ spinal nerve block in patients with migraine.

No conflict of interest.

Published: 18 September 2014

doi:10.1186/1129-2377-15-S1-D31

Cite this article as: Johnston et al:: EHMTI-0316. Exam findings predict outcome of $\mathrm{C} 1$ block for migraine treatment. The Journal of Headache and Pain 2014 15(Suppl 1):D31.
Submit your manuscript to a SpringerOpen ${ }^{\odot}$ journal and benefit from:

- Convenient online submission

- Rigorous peer review

- Immediate publication on acceptance

- Open access: articles freely available online

- High visibility within the field

- Retaining the copyright to your article

Submit your next manuscript at $\boldsymbol{~ s p r i n g e r o p e n . c o m ~}$
(C) 2014 Johnston et al; licensee Springer. This is an Open Access article distributed under the terms of the Creative Commons Attribution License (http://creativecommons.org/licenses/by/2.0), which permits unrestricted use, distribution, and reproduction in any medium, provided the original work is properly cited. 